\title{
"In the mountains, we are like prisoners": Kalinggawasan as Indigenous Freedom of the Mamanwa of Basey, Samar
}

\author{
Apple Jane Molabola ${ }^{1}$, Allan Abiera ${ }^{2}$, \& Jan Gresil Kahambing ${ }^{3}$ \\ 1 Professional Education Unit, Leyte Normal University, ORCID: 0ooo-0oo2-4568-9038 \\ 2 Social Science Unit, Leyte Normal University, ORCID: oooo-ooo2-8043-8832 \\ 3 Social Science Unit, Leyte Normal University, vince_jb7@hotmail.com, ORCID: oooo- \\ ooo2-4258-0563
}

\begin{abstract}
The Lumad struggle in the Philippines, embodied in its various indigenous peoples (IPs), is still situated and differentiated from modern understandings of their plight. Agamben notes that the notion of 'people' is always political and is inherent in its underlying poverty, disinheritance, and exclusion. As such, the struggle is a struggle that concerns a progression of freedom from these conditions. Going over such conditions means that one shifts the focus from the socio-political and eventually reveals the ontological facet of such knowledge to reveal the epistemic formation of the truth of their experience. It is then the concern of this paper to expose the concept of freedom as a vital indigenous knowledge from the Mamanwa of Basey, Samar. Using philosophical sagacity as a valid indigenous method, we interview ConchingCabadungga, one of the elders of the tribe, to help us understand how the Mamanwa conceive freedom in the various ways it may be specifically and geographically positioned apart from other indigenous studies. The paper contextualizes the diasporic element and the futuristic component of such freedom within the trajectory of liberation. The Mamanwa subverts the conception of freedom as a form of return to old ways and radically informs of a new way of seeing them as a 'people.' It supports recent studies on their literature that recommend the development of their livelihood rather than a formulaic solution of sending them back to where they were. The settlement in Basey changes their identification as a 'forest people' into a more radical identity.
\end{abstract}

Keywords: Mamanwa, Kalinggawasan, Indigenous, Freedom, Basey, Sagacity

\section{In search of freedom: the Mamanwa as "Indigenous people"}

The Lumad ("native") struggle is an ongoing plight of the indigenous, particularly in the southern region of the Philippines. The Mamanwa indigenous people is one such group that came from the south. The concept of the indigenous seen within the context of struggle substantiates a fundamental opposition that modern society, until now, has imposed upon the identification of the people embodying it. As Ghosh (2010, 37) inquires:"Why do the indigenous and the modern appear as opposed terms? Why should indigeneity always evoke an opposite temporality-'fastchanging,' 'modern,' 'contemporary,' and 'twenty-first century'? How does this binary structure invest our discourse of indigeneity even in its most critical moments?" It is important to ask such questions because the rejoinder can only point to contextual realities experienced by the people themselves. Continues Ghosh, "indigeneity and the concept of indigenous people are particularly

(C) AesthetixMS 2020. This Open Access article is published under a Creative Commons Attribution Non-Commercial 4.o International License (http://creativecommons.org/licenses/by-nc/4.o/), which permits non-commercial re-use, distribution, and reproduction in any medium, provided the original work is properly cited. For citation use the DOI. For commercial re-use, please contact editor@rupkatha.com. 
pronounced examples of a conflict that deeply informs the operation of the modern concept of "people" (Ghosh, 2010, 37). Concerning this opposition, Giorgio Agamben notes that

Every interpretation of the political meaning of the term "people" must begin with the singular fact that in modern European languages, "people" also always indicates the poor, the disinherited, and the excluded. One term thus names both the constitutive political subject and the class that is, de facto if not de jure, excluded from politics. (Agamben, 2000, p. 176; Emphasis added).

Against this backdrop, one notices that the Mamanwa as a people does not only imply the indigenous composition of their identity but also the inherent poverty, disinheritance, and exclusion that pervades it. It cannot be evaded therefore how the context of the indigenous peoples (IPs) is always going to point back to the referent distance that it is placed within politics. This is to say that politics is such a complex web of interpellations that always operate on their plight. The political authority that subjects this plight is covered by sovereignty so that autonomy also becomes a point of inquiry. Because "the people' appear as the abject: the embodiment of oppression, subjection, and powerlessness,"its identified basis points to their invention as "dominated and disempowered" (Ghosh, 2010, 37).

The significance of this paper stems from the fact that "indigenous societies change over time" (Coates, 2004, 118). That is to say, the formation of new knowledge concerning their plight becomes a matter of reframing them into theories that do not necessarily solidify into dogmatic illustrations. The struggle of the indigenous (and consequently, of the Mamanwa) must rest on a trajectory that maps this into a track of liberation. It was already situated how, through Zizek'svanishing mediator (Kahambing, 2018) and Butler's performativeindigeneity (Kahambing, 2019), the Mamanwanindigeneity suggests a liquid formulation of indigenous knowledge. Through this struggle of a people via Agamben, the paper aims to elucidate on an indigeneity that "emerges here as a trajectory of progress; the trajectory of a movement from an abject past to a liberating present" (Ghosh, 2010, 37).

The Mamanwa are considered "forest people," living in the mountains, roaming around the hinterlands hunting, tilling, and foraging (Kahambing, 2018). Placing this within the modern contrast of civility, being aetas with black physiognomy, they are discriminated in more advanced societies. Going into the political aspect of their struggle, one can note their alleged assimilation to the rebels who also reside in high places. Much of their struggle has been situated along withdiasporic experiences - of a long journey from Surigao to Basey (Kahambing, 2018), which is a byproduct of many concerns such as economic, political, and precarity (Kahambing, 2019). Hence, the question of migrancy cannot be viewed within a singular or binary approach of either want or need. It is a matter of want because of uway(rattan) is abundant in the islands of Leyte and Samar. It is also a matter of need - survival, life-struggle - as politics in the archipelago pushes them to do so. But it is, additionally, a matter of precarity as well because the conditions for their existence intersect many aspects of uncertain trajectories. Mapping the struggle of the Mamanwa has to deal with the condition of freedom that might be formed during their diasporic plight and their settlement. For over 70 years (1950-2020) of migrancy and eventual stay in Basey, Samar, understanding their idea of freedom already is an indigenous issue to be discussed.

There is an important shift that happens here from the socio-political to the epistemological formation of ontological conditions that point to specific veracities of their lives. Worth noting then is that the term "freedom, treated as more or less synonymous with equality, appears as if it were semiotically self- sufficient, as naming a 'truth"” (Rifkin, 2017, 56). And this truth can only be conceived within a struggle. As Smith $(2013,27)$ states, "the struggle for freedom 
has been viewed by writers such as Fanon as a necessarily, inevitably violent process between 'two forces oppose to each other by their very nature'." As such, "indigenous people is the name of one of the most active inhabitation of this constitutive opposition" (Ghosh, 2010, 37).

Tied to the veracity of their existence, the Mamanwa's "indigenous knowledge" about freedom is based on their communal understanding and "is embedded and conditioned by the culture of the locality in question. The development of indigenous knowledge is a byproduct of efforts to master the environment and has been a matter of survival to the communities" (Ezeanya-Esiobu 2019, 6). The need to situate the Mamanwa in their locality in Basey, which is now different from other Mamanwas throughout the country, backs Sillitoe who said that indigenous knowledge is a

Culturally informed understanding inculcated into individuals from birth onwards, structuring how they interface with their environments. It is also informed continually by outside intelligence. Its distribution is fragmentary. Although widely shared locally on the whole than specialized knowledge, no one person, authority or social group knows it all...It exists nowhere in totality, there is no grand repository $(2002,9)$.

Therefore, it is becoming vital to specifically pinpoint how the Mamanwaof Basey, Samar conceive their own experience of freedom. In what way must we understand the fragments of their experiences and make sense of their connection.

\section{Indigenous Methodology}

Among the various indigenous research methodologies, the paper utilizes the philosophic sagacity methodology via interview. Under this method, "the theory of knowledge and questions about knowledge can be found in the wisdom and beliefs of wise elders of the communities, who have not been schooled in the formal education system" (Kaphagawani\& Malherbe, 2000 as cited by Chilisa, 2019, 180). It is an

... important epistemological assumption" that "methods based on philosophic sagacity enable researchers to consult a large body of knowledge from the sages that is not available in the written literature. (Chilisa, 180)

Such a method is reflective of the wisdom and traditions of people (Emagalit, 2001). The sages are the "elders and members of cultural committees" (Mkabela, 2005) or could be "any identified key informant" (Weber-Pillwax, 2001). Our identified key informant is Conching Cabadungga, a 68year-old elder of the Mamanwa community in Basey. She is among those who have undergone the diasporic experience and can thus perfectly relate to the formation of knowledge in the tribe. As such, the study's scope concerns only to this specific tribe of the Mamanwa in Basey apart from other Mamanwa tribes throughout the country and even within the Eastern Visayas region to which it belongs.

The interviews are non-structured and are a series of questions that can be weaved together. They are recorded, transcribed, translated, and reviewed for accuracy. However, as a limitation, this article cuts and splices only the responses relevant to the topic at hand. Other topics have been archived for future research reference and the recordings of the interviews can be requested as the need arises.

There is a methodological problem encountered in this article and it is largely analytic as problems of translation cannot quite fully associate the formation of exact Mamanwan terminologies, which are absent in extant literature. What usually happens is that whenever we try to shape a coherent pathway to the understanding of a term, there is the tendency to repeat 
and appeal to it through the researchers' symbolic language. As such, the formulation of Mamanwan freedom, in this case, aptly translated as Kalinggawasan, variably comparable to the Cebuano or generally Binisaya term Kagawasan - whose roots may be tied to the proto-Manobo language of the tribe (Dyen, 1965/1963; Pallesen, 1985) - is treated as a liquid concept specific only to the symbolic and geographic hermeneutics shared by both the researchers and the informant cultural bearer.It is helpful that the researchers are knowledgeable with the Binisaya language Waray and Cebuano - which has a semblance with the Surigaonon language in which the tribe spoke of near their own Minamanwa. It is vital in this paper that the responses are kept on a 'near-verbatim' transcription with English translations on the side. Moreover, it should be noted that Conching's interviews have been backed by Jennifer Cabadungga, the Mamanwa chieftain, whenever clarifications to answers are necessary, since the formation of indigenous knowledge, though collective, can sometimes have lapses in the oral testimony. Throughout the interviews, Jennifer is sitting beside Conching. The conversational non-structured interview with the researches allowed us to be "active partners in the co-creation of contemporary indigenous knowledge" (Weber-Pillwax, 171).

With legal and official designation, the authors are involved in the long-term research and extension project started in 2017 entitled 'Documenting the Life \& Culture of the Migrant Mamanwa of Basey, Samar.' This formed part of the 'LNU: Lending a hand. Building a future' initiative in cooperation with the United Nations Educational, Scientific and Cultural Organization (UNESCO) and National Commission on Indigenous Peoples (NCIP), Philippines, inclusive of ethical protocols and institutional authorizations. One of the co-authors of this paper, under the same agreement, has already published about the Mamanwa (Kahambing, 2018; 2019) despite the dearth of literature, has corresponded with other researchers on the Mamanwa in Biliran, Surigao, and Southern Leyte, and can thus qualify for the sagacity method in further informing, reviewing, and reassessing the literature to them. All this does not, however, forget the fact that "indigenous interview strategies, based on philosophic sagacity, invoke indigenous worldviews of the colonized Other" (Chilisa, 174).

\section{Mountains as prisons: Contextualizing diasporic freedom}

It is one of prevalent assumptions to see the indigenous as belonging only to a place. This provides the perspective that incorporates a "look to traditional Indigenous knowledge as being more attuned to ecological insights" (Monani, 2016, 56). That the Mamanwa, for instance, are dependent on the forest for sustenance directs the gaze to their connection to ecological knowledge. But this view, quite interestingly as this study suggests, has already changed from their diasporic experience. Adaptive mechanisms play a role in this regard, acknowledging that adaptation "is a central theme in the history of indigenous response to the arrival, advance, and activities of newcomer populations" (Coates, 2004, 118). The radical judgment in this regard distances the bias towards the indigenous as belonging to an ecological site. Conching adjudges that "bisanwa nay mutulongnamongaahensiya di nagud mi mubaliksalasang (Even if there are no more agencies that will help us, we will never go back to the forest)." When asked why they won't go back to the forest, she replied "kay kanang, unsani...uwayra man amopakabuhi, itongpag-uma, takaydinhiusahaymakapalit kami hinbugas, may mgaahesiyanamaduol ha amonmahatag (Because, what is this...rattan is our only source of income, through tilling, but here we can sometimes buy rice, there are agencies that come and give us)."

The economic motive of gathering rattan has been reported by Ponce (2018) and is shared by the Mamanwas of Surigao. However, this is no longer shared by the Mamanwa of Basey as changes in the environment throughout their constant habituation already inform them of the 
scarcity of resources. Says Conching: "Angubod....didtosalasangwangani...makahilakangmgabata kay ubodra man ... manguha mi ugubodtaposipakaonsamgakabataankanang.... (There are no banana shoots in the forest anymore... [before] the children are crying because they are only eating shoots. We'll get shoots and that's what we feed them)."

It might be argued that banana shoots are rich in fiber and can be considered healthy but Conching retorts that actually, it is painful: "Nah kay hapdossatiyan (It stings in the stomach)." Other food variants that they get and improvise from the forest are: "Kanangarasiponba...Gunawba, gunaw (banana shoot soup)" and "bukagsabalanghoyiraidonnimo may bukagbahiya. Amoito it pagkaonnamon (Casava inside rattan baskets that we make. That's what we eat)."

The transition from food gathering is an important aspect of the change in their conception of freedom. There is freedom in roaming, even with the economic motive of bringing in food for the tribe or gathering resources for crafts, but the stability forms an attractiveness that for them can only be found in the settlement. The fact of the matter is that agencies will not be chasing them had they not stayed in a place so that the genitive of Basey becomes a vital geographical position informing us of their settled freedom. This is to say that from years of diaspora, the conception of Mamanwan freedom also shifts its understanding. If the concept diaspora acts as a vanishing mediator (Kahambing, 2018), then the identification that produces the indigenous knowledge of freedom from the Mamanwan vantage point also means that there is no going back, practically, to such a diasporic life. The mediation of diaspora is simply performativeindigeneity (Kahambing, 2019) that acts on their precarious life: as an indigenous people, the performative enables them to reveal the truth about themselves. Conching says that "Kung may mga livelihood sugadpalitnamomgabaktin kung unsa bay ikalooysaamosamgaahensiyanamakadi ha amon kay angmamanwagud...mahirapgudtalaga (If we have livelihood like hog raising, whatever help from agencies that come here, because the Mamanwa is poor, really)."

The mountains, which was formerly tied to the Mamanwan identification - the first instance of freedom that they experienced away from Surigao - is not enough, so that the mountains eventually revealed other forms of precarity and poverty. The graphic picture that they see in this resembles a place of difficulty, unliberated, and chained in a certain way of life. Says Conching: "Amonangadilina mi mubaliksalasang kay malisodjud (That's why we won't go back to the forest anymore because life is difficult there)." The freedom to roam, in other words, which we might call 'diasporic freedom" is just the beginning of another difficult journey and as such is not a complete manifestation of freedom. The happiness that diasporic conjures in this account pales over the happiness that they get in settling in Basey. Jennifer Cabadungga, the Mamanwa chieftain, backs Conching's statements:

Oo, para namonaa mi kagawasan dire saduolsabaranagaytungodngaduolnaangpagpaeskwelanamosamgaanakunya kung unsaamokinahanglanonsaamopangihanglanpamalitduolnasamgatindahan, sugadhito. So, kundidto pa kami ha bukidparangpriso kami didto, parangnakakulong kami kasimalayo kung anokailangan naming malayo naming maabot. So, sadinhina kami ha baba, naanona kami dinhi ha harani ha barangay, so amoadtoparangnakagawas kami hanmakurinamakakanhina kami harani ha barangay. Kay kun may mga emergency natabangandayon......

(For us, we have freedom herenear the barangay because schooling is accessible for our children and our needs can be bought in the stores. So, in the mountains we are like 
prisoners, because our needs are far from reach. That's why we are here down below, near the barangay. We are freed from and it was a difficult journey. Here, there is help in times of emergency.)

For Conching there is happiness outside the mountains, which reiterates Jennifer's words: 'in the mountains, we are like prisoners.' As long as they stay in Basey and agencies will focus on giving them livelihood, that is what happiness is about according to Conching: "Kung naa mi pakabuhi, Malipaygud kami sir, malipaygud. (If we have livelihood, we will be happy, very happy)." The crucial aspect of diasporic freedom, therefore, is freedom from. In the case of the Mamanwa of Basey, it is freedom from the mountains and Jennifer precisely caps this point: "Angamokagawasan is nakaari mi sa barangay is nakagawas mi salayodidtosabukid so dire na me saduolsabaryonakaukoy (Our freedom is arriving here in the barangay, freed from the hinterlands, so that we are living here near the barrio)."

\section{Struggling to live: Kalinggawasan "for" or Mamanwan Freedom}

There is another further aspect to diasporic freedom for the Mamanwa and that is the fuller conception of freedom as a struggle to live. The idea is that this more complete definition encapsulates a deeper sense of their experience. To situate this, Conching contextualizes how past practices enabled them to conceive freedom as a deflection or escape:

“Aw! HadtoanbalitanamagbalhinbalhinangMamanwatribu kay wala man nag atimansaamonamgaahensya. Bale, sarilinamonnabisanasa kami mabuhi. Kanangbadsangbitawnakaunonsalasang. Mangita mi makaonsalasangnabadsang. Kanang "gunaw". Hadto, ngadto kami uway, nahuron kami. Asyaiton (Before, the news is that the Mamanwa are nomads but that's because no agency is taking care of us. We lived on our own depending on where we can find resources. In the forest, we eat taro corm variants, then soup. Before, we stay in a place to get rattan)."

The epistemic development of Mamanwan freedom can be said to be abstractive but it is a lens that also helps them understand their own. A fundamental point in anthropological studies is that "people's knowledge fundamentally represents a response to intellectual needs" or that "people are not concerned with developing any knowledge beyond the pragmatic concerns of everyday life" (Crossman \&Devisch, 2002, 105). The Mamanwa are more concerned with pragmatic matters and these shape in diasporic freedom a futuristic element. Without this grounding, any theoretical perspective that can inform us of their plight would be futile. The Mamanwa are thankful that they can think about such matters when agencies come to their aid. Philosophical sagacity in this regard enabled Conching, who wasn't able to go to school along with other elders, to co-create with us knowledge that concerns their living. As was mentioned, schooling became accessible and this helps them think about other things albeit in connection to how they live. She narrates,

Oo, maramingnatulongtaposlabina kay pagkuansa Yolanda nganawasak among pag-ukoy, among mgabalaytapos gin balayan kami hininga AGKOP, asyaini nag-pasalamat kami namayda kami balaypero ha balay la waraytulong ha amonngapakabuhianba. Angsarililangnamonngapakabuhi, manhimohinbanig, uway, kaing...........makapalit la hanbugas. KahirapanlagisaMamanwatribu kay agiansa Yolanda namahirap. Pasalamat kami kay naamgaahensiyangabisandiinnatulong ha amon, nabuliggihapon. Nganakapasalamatakoakongmgaaponaka-eskwelataposakongairanglolo,

lolawarayakopakaeskwelabisan Grade 1, waraygudasyaitonnga kun interbyuhonakosugadako, nawowoworog *(laugh) 
(There are lots of incoming help especially when [super typhoon] Yolanda destroyed our home, our houses. Then the ABCCOP [Alliance of Bible Christian Communities of the Philippines] made us shelters. We are thankful that we now have houses, but only houses no livelihood. Our livelihood consists of making tikogmats, rattan, bamboo basket - just enough to buy rice. The Mamanwa tribe is poor, then Yolanda came. We are thankful that there are agencies that help us. I am particularly thankful that my grandchildren can go to school since I and their grandfather weren't able to go to school, not even on the $1^{\text {st }}$ grade. That's why when I am interviewed, that's just how speak.)

The very kernel of this freedom was uttered by the chieftain herself when asked what the word freedom meant to them: Kalinggawasan. On the outset, this substantiates being away from the mountains but it also means that because they are now near the barrio, they have a new way of becoming free and at present, it can still be embodied within their struggle to live. The grand scheme is that the messy, "often violent," yet "occasionally mutually beneficial meeting of cultures, societies, and values shaped the human history of much of the globe and established the foundation for efforts by indigenous peoples to make their way in a complex, integrating and often aggressive world" (Coates, 119). But being free this time means that they are going to struggle to stay. In the words of Conching: "Saakonghuna-huna, maonanianglugarnamongapuyan judnga dire najud mi magpuyonawala nay makapugongnadili mi makapadayon dire pagpuyo. So, padayonnajudnamo. (In my mind, this is the place where we can stay. No one can stop us in our stay here. This is where we'll carry on)."

What is consistent in the identity of the Mamanwa, moreoever, is their generosity and love for peace (Masinaring, 2011). Such attitudes can be coupled with their development. The admirable traits, particularly the concerns for the tribe and the family, are there to stay for Conching even in the context of struggle: "Pamilya, pamilya..pero kun waray an usakabalay, wajud lung-agontagaan. Puromabuhi la, kay mahirap man kami didi. Kay sarili la man namonnapakabuhi... (The money is for the family. But if other households don't even have rice to eat, we share. It's all a matter of struggling to live because we are poor. We struggle to sustain our own...)." Mapping the specific knowledge of the Mamanwa for freedom as the struggle to live cannot, of course, easily do away with the bigger picture of the indigenous as a whole. "In many locations - Brazil, Argentina, the Philippines, and temperate parts of Africa - indigenous peoples were pushed off arable land and forced onto unattractive territory where they struggled to maintain a living" (Coates, 189). Kalinggawasan as Mamanwan freedom is very specific in its complete description. It is the freedom from catastrophes, freedom from armed terror, and freedom from violence.

Amo la bay nahunahunaannakon, an simbakoagia-an kitahinbagyongamangabuhi la, magpasalamatnawaray ma hingadto ha karat-an... Simba ko mg-gubotnga dire kami maunsa may malooyba ha amonna dire kami pagunsahondidi kay mgamahirap, waray man kami mgasala, asyaito, magpakabuli la kay mahirap man. ([In defining freedom,] What I can think of is that, God forbid, in times of catastrophes, we could be thankful that we are delivered from danger [...] that, God forbid, when there is armed conflict, we wouldn't be involved, that mercy will be given to us... [Freedom is] when we are not forced from something because we are just poor. We don't do anything wrong. We are just struggling to find a living.)

From these 'freedom froms,'Conching appeals that in their struggle, livelihood is given them. They understand that they are still precarious: they are still an indigenous 'people.' The difference 
is that Kalingawasannow becomes a freedom for because there is a future. In Basey, they have become a people with a future. She says,

“angpanginahanglannamo, angamopanginahanglangudangkungano it pakabuhian....kung satagalog pa, itulong ha amonnga dire na kami magkuhahanuway dire kami manhimohinbanigngaadinalaamonpakabuhi kun..... (Our needs, our basic needs are our livelihood...in Tagalog, help us so that we can get rattan and make tikog mats here - that we can live here)." When asked what else can hinder their freedom in Basey, she acknowledges the lack and ongoing struggle: "daghan pa, damo pa (There are still many)."

In conclusion, the Mamanwa subverts the conception of freedom as a form of return to old ways and radically informs of a new way of seeing them as a 'people.' It supports recent studies on their literature that recommend the development of their livelihood rather than a formulaic solution of sending them back to where they were. The settlement in Basey changes their identification as a 'forest people' into a more radical identity.

\section{Notes}

${ }^{1}$ The use of 'diasporic' refers to the mediation that occurred as the experience of the Mamanwa in the sense of a vanishing one which characterizes the incompleteness and soon-to-be completion of its task through their eventual stay in Basey. The term 'diaspora' in a previous study was already critiqued as a non-viable diagnosis for their plight. See Kahambing (2018)

\section{References}

Agamben, G. (200o). Means without ends: Notes on politics (Trans. Vincenzo Binetti and CesareCasarino). Minneapolis: University of Minnesota Press.

Chilisa, B. (2019). Indigenous research methodologies. Sage Publications, Incorporated.

Coates, K. (2004). A Global History of Indigenous Peoples: Struggle and Survival. Palgrave Macmillan.

Crossman, P., \&Devisch, R. (2002), Endogenous Knowledge in Anthropological Perspective. In Hoppers, O. C., Indigenous Knowledge and the Integration of Knowledge Systems. Towards a Philosophy of Articulation (pp. 96-127). Cape Town: New Africa Books.

Dyen, I. (1965). The Lexicostatistical Classification of the Austronesian Languages. New Haven. [Originally published: 1963].

Emagalit, Z. (2001). Contemporary African philosophy. Retrieved from http://homepages.acc.msmc.edu/faculty/lindeman.af.htmls

Ezeanya-Esiobu, C. (2019). Indigenous Knowledge and Education in Africa. Springer Nature.

Ghosh, K. (2010). Indigenous Incitements. In Kapoor, D., \&Shizha, E. (Eds.), Indigenous knowledge and learning in Asia/Pacific and Africa: Perspectives on development, education, and culture (pp. 35-46). Springer.

Kahambing, J.G. (2018). Diaspora as Vanishing Mediator: Emancipation of Identity for the Mamanuas of Basey, Samar. In Galang-Pereña, F., Ampil, R., Gonzales, E., \& Lazaro-Zamora, N. (Eds.), Philippines and Asian Studies: Expositions, Explorations, and Expectations (pp. 183-200). Rizal: Word Prints Publishing Services, Inc.

Kahambing, J.G. (2019). Theorizing mamanuan diaspora: From vanishing mediator to performativeindigeneity. Rupkatha Journal on Interdisciplinary Studies in Humanities, 11(2), 1-15. 
9 | References

Kaphagawani, D. N., \& Malherbe, J. G. (200o). African epistemology. In P. H. Coetzee \& A. P.J. Roux (Eds.), Philosophy from Africa (pp. 205-216). Oxford, UK: Oxford University Press.

Monani, S. (2016). Science Fiction, Westerns, and the Vital Cosmo-ethics of The $6^{\text {th }}$ World. In Monani, S., \& Adamson, J. (Eds.), Ecocriticism and indigenous studies: Conversations from earth to cosmos (pp. 44-61). Routledge.

Pallesen, A. K. (1985). Culture contact and language convergence. Philippine Journal of Linguistics, special monograph issue 24 .

Ponce, B. (2018). Speck in the Vast World of Economy and Politics: An Economic Anthropological Study of the Mamanwa in the Philippines. Asia Pacific Journal of Multidisciplinary Research, 6(2), 97-104.

Rifkin, M. (2017). Beyond settler time: Temporal sovereignty and indigenous self-determination. Duke University Press.

Sen, A. (1999). Development as freedom. Oxford University Press, Oxford

Sillitoe, P. (2002). Making anthropology work. In Sillitoe P., Bicker, A., Pottier, J. (Eds), Participating in development: approaches to indigenous knowledge. Routledge, London

Smith, L. T. (2013). Decolonizing methodologies: Research and indigenous peoples. Zed Books Ltd..

Weber-Pillwax, C. (2001). What is indigenous research? Canadian Journal of Native Education, 25(2), 166-174. 